\title{
Tall Tales for a Mass Audience
}

\section{Dutch Penny Prints and Spanish Aleluyas in Comparative Perspective}

\author{
Juan Gomis | ORCID 0000-0003-0458-5555 \\ Professor in History, Catholic University of Valencia, Valencia, Spain \\ juan.gomis@ucv.es \\ Jeroen Salman \\ Assistant Professor Comparative Literature, University of Utrecht, Utrecht, \\ Netherlands \\ j.salman@uu.nl
}

\begin{abstract}
In this article we compare Dutch penny prints with Spanish Aleluyas, focusing on three specific functions of this premodern mass medium: popularising and adapting theatre plays; standardising (folk/fairy) tales; adapting and popularising literary classics. Via these functions we address the discrepancies between the two countries considering the materiality of the penny prints, the growth of the production, but also the transition from a predominantly religious, towards a more profane content. Striking was the lack of educative and edifying initiatives in Spain in contrast to the Dutch ideological strategies. We observed some interesting similarities as well. Although in both countries penny prints often conformed to current ideologies and institutions, there were instances in which penny prints and aleluyas were used as instruments of social satire or resistance. A few similar strange twists in the adaptations of literary classics, seem to suggest some form of transnational exchange or at least imitation.
\end{abstract}

\section{Keywords}

penny prints - aleluyas - Spain - The Netherlands - social functions adaptation - popularisation 
Penny prints are a ubiquitous, varied, cheap and colourful phenomenon in the history of European popular print. Although they are often seen as a precursor of our cartoon or comic strips, due to the combination of text and image, penny prints deserve to be studied in their own right. In material terms we can best define them as broadsides, printed on one side. Although the bibliographical format is plano and the exact size could differ, the size of the used paper sheets for this genre were more or less standardized in the Netherlands and Spain and also did not differ very much in both countries: in the Netherlands typically 30 to $42 \mathrm{~cm}$ and in Spain typically 32 to $44 \mathrm{~cm}$. They were illustrated with small woodcuts, ranging in general from as few as 8 to as many as 48 woodcuts.

The Dutch penny prints were usually coloured manually, which meant that they could be sold for a higher price. This (sketchy) colouring was often done by women and children (with a brush or tampon) paid very low salaries. Only from the nineteenth century onwards (especially among some Belgian firms) did publishers start to use templates for the colouring, which strongly improved the quality. Colouring popular print was not only done to give them more appeal, however. According to David Hopkin cheap print needed to be brightly coloured because it often ended up in dark cottages, houses and inns, pasted or pinned against the wall. ${ }^{1}$ In Spain, colour was an important feature too, but in a different way. From the end of the nineteenth century, the paper itself was often coloured (either blue, green, yellow or pink) to make the printed product more eye-catching. Rhyming captions below the images either narrated the story or explained the (non-fictional) pictures. ${ }^{2}$ A miscellaneous world of wonders was represented in these prints, running from topography, fashion and natural history, to bible stories, lives of saints, historical heroes, allegories, fables and fictional narratives.

Penny prints can be found in many European countries, although they made their first appearance and were popular in different periods, were not always equally diverse, and were called different things. In most countries print publishers did not only produce separate titles, but focused on series of penny prints, which were numbered in order to encourage consumers to collect them. This marketing technique was not only a successful commercial strategy, but also helps researchers to reconstruct publishers' lists. The name by which penny prints were known in different language-areas could be related either to

1 D. Hopkin, 'Ballads and Broadsides in France: Accounting for an Absence', in: Cheap Print and the People: European Perspectives on Popular Literature, ed. D. Atkinson \& S. Roud (Newcastle upon Tyne 2019), p. 81. All links were last accessed 28/o8/2020.

2 N. Boerma, A. Borms, A.Thijs \& J. Thijssen, Kinderprenten, volksprenten, centsprenten, schoolprenten: Populaire grafiek in de Nederlanden, 1650-1950 (Nijmegen 2014), p. 66; A. Borms, Centsprenten: Massaproduct tussen heiligenprent en stripverhaal (Zwolle 2010), p. 8, pp. 14-16. 
their low price, the content, the intended audience, or the place of production. Sometimes different names circulated in one country, due to different dialects, changing functions, bibliographical decisions or new audiences. In the Netherlands for instance we encounter 'kinderprenten' (prints for children), 'centsprenten' (penny prints), 'volksprenten' (popular prints) and 'schoolprenten' (school prints). In Spain, these prints were known under the heading 'aleluyas' and 'auques' (this last term was used in Catalan-speaking regions). In other European countries the following (contemporary or modern) terms were or are used: 'Catch penny prints' (England), 'Imagerie populaire', 'Images d'enfants', 'Image d' Épinal' (France); 'Bilderbogen', 'Neurupinner' (Germany), 'Stampe popolari', (Italy), 'Mannekensbladen' (Belgium); 'lubok' (Russia); 'folkelige grafik' (Scandinavia). ${ }^{3}$

In addition, it is important to stress the transnational dimensions of this material. There were specific national features, but we encounter many similarities, mutual influences, and forms of collaboration. Furthermore, there were firms that were not bound to borders or language areas, but targeted very large geographical areas. The Remondini publishing house (in northern Italy) is a case in point, but there are other (less well-known) examples as well. The Pellerin publishing house in Épinal in France published penny prints for a Spanish public too. They produced both bilingual versions (such as 'Combats de taureaux-Corrida de toros') and series of aleluyas exclusively in Spanish (at least 6o titles), including some for the Latin American market. The Olivier-Pinot publishing house, also in Épinal, published penny prints in Spanish, inserted in its series of prints in French. And the Dutch/Belgian firm Brepols published bilingual penny prints in Dutch and French. ${ }^{4}$

\section{A Mass Medium with a Long History}

In terms of titles, series, editions, publishers and printed copies the figures that feature penny prints in the Netherlands and Spain are impressive and justify the qualification 'mass medium'. An interesting difference though, is that in the Netherlands the production started to bloom in the eighteenth century, whereas in Spain - as in many other European countries - the main growth followed a century later. It is difficult to give just one concrete explanation for

3 See also A. Borms, Grensland, prentland: Turnhoutse Mannekensbladen (Turnhout 2012), p. 13.

4 J. M. Martínez González, 'Ediciones en español de imaginería popular europea durante el siglo XIX', in: Simposio sobre literatura popular. Imágenes e ideas: La Imaginatura, ed. J. Díaz (Urueña 2012), pp. 4-45. 
this, but more in general we assume that it has to do with the relatively high level of literacy in the Dutch Republic, a blooming and competitive publishing industry (starting already in the seventeenth century), a good infrastructure (especially waterways) and a large market of (well-to-do) buyers.

In the Dutch Republic, the number of penny print publishers rose from 10 in the beginning of the eighteenth century, to 30 at its end. The average print run in that period was between 12,000 and 25 ,000 copies. ${ }^{5}$ Due to the low production costs and a lucrative, large market, several generations of publisherprinters continued the production for many decades. The Van der Putten dynasty in Amsterdam, for instance, was active between 1728-1794. From 1768 onwards they produced a series of no fewer than 158 different titles. ${ }^{6}$ When we take into account that from every new title at least 12,00o copies had to be sold to earn a profit, we can start to envision the huge numbers that must have flooded the market in the eighteenth century. ${ }^{7}$

Due to a unique, preserved account book we know that in 1792 the Amsterdam publishing house Stichter sold 277,00o copies of penny prints to booksellers in and outside Amsterdam. ${ }^{8}$ On the basis of these and other figures, it has been estimated that at that moment the total production in the Dutch Republic must have been around 1 to 1.5 million penny prints annually. ${ }^{9}$ This implies that on a yearly basis at least one print per every two Dutch inhabitants was available. ${ }^{10}$ For the nineteenth century we have more systematic data from the Belgium publishing house Brepols in Turnhout. In that period a large proportion of the production-capacity moved to the Southern Netherlands (current Belgium), albeit that the Northern Netherlands (the area of the Dutch Republic) remained a substantial market. In 1829 250,080 copies, printed at Brepols, were sold in the Northern Netherlands and in 1857 this had risen to 607,200 copies. ${ }^{11}$ Estimates have been made for Belgium and the Netherlands together that give a good indication of the massive production in

5 Boerma et al., op. cit. (n. 2), pp. 136-140; P. Vansummeren, Kinderprenten van Brepols (Turnhout 1996).

6117 of these different titles have survived. Boerma et al., op. cit. (n. 2), pp. 220-2.

7 Boerma et al., op. cit. (n. 2), p. 75.

8 Amsterdam, City Archive, Toegang 506o, Koopmansboeken, inv. no. 185.4, Boekverkopersboeken van de Erven Stichter, 1787-1792.

$9 \quad$ Boerma et al., op. cit. (n. 2), p. 76.

10 J. de Vries \& A. van der Woude, Nederland 1500-1815: De eerste ronde van economische groei (Amsterdam 1995), p. 96.

11 Vansummeren, op. cit. (n. 5), p. 195. 
the nineteenth century: between 2.5 and 4 million penny prints in the first half and 6 and 9 million prints in the second half of that century. ${ }^{12}$

For nineteenth-century Spain the figures are also highly remarkable. Publishers such as Tabernillas (Madrid) published a series of 85 aleluyas, Boronat (Madrid) 69 and Llorens (Barcelona) 68. As far as we know, the most extensive series was the one produced by the publishing house of José María Marés and his successors, Manuel Minuesa and Hernando, located in Madrid, who printed more than 140 different aleluyas between 1845 and 1930. These titles represent a large number of editions, because just as in the Netherlands, it was common practice to reprint a specific aleluya several times. Some successful titles even counted 10 and 12 reprints. Although there is little concrete data about print runs, we encountered cases of 75,000, 70,000 or 45,000 copies made from a title. ${ }^{13}$ This means that, even without taking the usual reprints of a title into account, Marés, Minuesa and Hernando, for instance, must have printed more than one million aleluyas. These huge numbers are consistent with the amounts of all sorts of other popular genres in stock, as found in some printers post-mortem inventories: 75,000 'pliegos sueltos' in Manuel Minuesa's printing house; 500,000 in Agustín Laborda's and 5 million in Hernando's. ${ }^{14}$

In the eighteenth century we can identify five Dutch centres where these prints were produced: Amsterdam, Deventer, Zaltbommel, Den Bosch and Rotterdam. From these centres the Dutch prints reached every corner of the country via pedlars and stall holders, via schoolmasters offering them in their classrooms (often as a reward) and via local bookshops. The distribution system was enhanced by an efficient network of publishers and 'wederverkopers' (retailers or resellers). Major publisher-printers with a large stock of prints distributed these copies to several smaller retailers and itinerant sellers all

12 Boerma et al., op. cit. (n. 2), pp. 75-7. See also J. Salman, 'An Early Modern Mass Medium: The Adventures of Cartouche in Dutch Penny Prints (1700-1900)', Cultural History, 7 (2018), pp. 20-47.

13 J.-F. Botrel, 'La serie de aleluyas Marés, Minuesa, Hernando', in: Aleluyas, ed. J. Díaz (Urueña 2002), pp. 24-43.

14 In Spain, 'pliego suelto' (single sheet) was the name given to the basic unit of paper that was used by all the printers to make books. The 'pliego suelto' was the basis of 'literatura de cordel'. Works of this kind were published on a single 'pliego suelto' folded twice (producing a booklet with eight pages), on half a pliego, or on two, three or four pliegos joined together. P. Fernández, 'Datos en torno a la bibliografía y difusión de la literatura popular en el Madrid del siglo XIX: la imprenta de Manuel Minuesa (1816-1888)', Anales del Instituto de Estudios Madrileños, 31 (1992), pp. 225-38, esp. p. 233; J. Gomis, 'Un emporio del género de cordel: Agustín Laborda y sus menudencias de imprenta (1743-1776)', in: Culturas del escrito en el mundo occidental. Del Renacimiento a la contemporaneidad, ed. A. Castillo (Madrid 2015), pp. 239-5o; Botrel, art. cit. (n. 13). 
over the country. A well-known publisher-printer in the city of Zaltbommel (Noman), for instance, collaborated with no fewer than 25 retailers. When these retailers purchased one ream (480 penny prints) or more, their name and address appeared on the imprint instead of that of the publisher-printer. ${ }^{15}$ Contemporary buyers therefore often knew the retailers and their addresses, but were usually ignorant about the original publisher-printer. These practices make it possible for modern-day researchers to chart the distribution network in detail, but form an obstacle to identifying the actual producers. ${ }^{16}$ As stated earlier, the production of penny prints moved to Belgium (mainly in Turnhout) in the nineteenth century. The aforementioned network of retailers ('wederverkopers') remained intact, however. Even after 1850, when many Dutch language penny prints were, remarkably enough, produced in print centres in France (Épinal, Pont á Mousson, Jarville-Nancy, Paris) and Germany (München, Neuruppin, Asschaffenburg, Weissenburg), the resellers-system and the widespread distribution in the Northern Netherlands was maintained. ${ }^{17}$

Madrid and Barcelona were the main centres of production of aleluyas and auques in Spain, although they were also printed in other, smaller cities. Their distribution channels were, basically, the same as those common for the literatura de cordel.' 'Pliegos sueltos' and aleluyas were sold from printers offices and bookshops, but their main form of dissemination was 'colportage', on the one hand carried out by professional or occasional pedlars at a local level, and on the other hand by big traders ('marchantes') who travelled through the country and offered reams of copies in cities, villages and rural areas. One of the peculiarities of the Spanish colportage was the role played by the blind, who since the sixteenth century had the sale of prints as one of their regular occupations. ${ }^{18}$ In the eighteenth century this link became even tighter, when some of the confraternities of the blind received a monopoly from the royal authorities to peddle 'pliegos sueltos' for a specific period of time..$^{19}$ Although these confraternities were dismantled in the nineteenth century, the blind kept selling popular prints, including aleluyas, as independent pedlars.

15 Borms, op. cit. (n. 2), pp. 14-16; J. Salman, Pedlars and the Popular Press: Itinerant Distribution Networks in England and the Netherlands 1600-1850 (Boston/Leiden 2014), pp. 237-43.

16 Boerma et al., op. cit (n. 2), pp. 78-89; Salman, art. cit. (n. 12), pp. 237-9.

17 Boerma et al., op. cit (n. 2), p. 89, pp. 139-140.

18 J. Gomis, 'Pious voices: Blind Spanish Prayer Singers', Renaissance Studies, 31-1 (2019), pp. $42-63$.

19 J. Gomis, Menudencias de imprenta: Producción y circulación de la literatura popular (Valencia, siglo XVIII) (Valencia 2015). 
This massive, wide-spread and long stretched occurrence of penny prints and aleluyas in Spain, the Netherlands and many other European countries, raises intriguing questions. How were these different forms, contents and functions related? Was there a transnational exchange of stories and images? Did they copy, translate or adapt foreign examples and did publishers, booksellers and engravers in different countries and regions collaborate? In this article we will try to answer some of these questions by making a comparison between penny prints in Spain and in the Low Countries (the Dutch Republic and the Southern Netherlands - current Belgium). Why these two countries? In the first place because in both countries the popularity of penny prints was exceptionally high. Secondly, after a first pilot study we realised that there were some striking similarities. And what is more, the Low Countries and Spain were in the sixteenth century part of one (Habsburg) empire. It is plausible that, aside from the shared political and religious ideologies and institutions, collaboration and influence was also common in the cultural field, with the printing industry providing a means of cultural exchange. This must have changed radically of course with the outbreak of the violent conflict between Spain and the Low Countries in the course of the sixteenth century. From that moment on especially the Northern Netherlands developed in a different religious, political, economic and cultural direction. It seems obvious that this divergence also led to different avenues in the publishing industry and in the production of popular print. Was this breach reflected in the content and function of penny prints and aleluyas? Although the focus of this article will be on the Netherlands and Spain, we occasionally refer to, or incorporate, material from other European countries when we think this will illuminate the comparison. ${ }^{20}$

A thorough comparison of this ephemeral material can only succeed when we have substantial and accessible collections. Fortunately, Spain as well as the Netherlands, are blessed with rich collections of penny prints, partly also digitised and online. In the Netherlands we encounter several private collections, either donated to public libraries or made available online, such as those of Nico Boerma, Aernout Borms, Jo Thijssen, Marc Cornelis, Jan Anderson and Arie van den Berg. Large collections can be found in public institutions such as the National Library in the Hague, the Rijkmuseum (Prentenkabinet), the University Library of Amsterdam, the Openlucht museum in Arnhem, the Fries

20 See for these other European penny prints: J. Mistler, et al., Épinal et l'imagerie populaire (Paris 1961); P. Stephen Falla \& S. Lambert, French Popular Imagery: Five Centuries of Prints (London 1974); Th. Gretton, Murders and Morality: English Catchpenny Prints, 1800-1860 (London 1980); E. Hilscher, Die Bilderbogen im 19. Jahrhundert (Munich 1977); D. Kunzle, The Early Comic Strip: Narrative Strips and Picture Stories in the European Broadsheet from c. 1450 to 1825 (Los Angeles 1973). 
Museum in Leeuwarden and Museum aan den Stroom in Antwerp. ${ }^{21}$ For Spain, the main collections of aleluyas and auques are located in the City Historical Archive of Barcelona, the National Archive of Catalunya and the Joaquín Díaz Foundation (the last one is digitised). ${ }^{22}$

In the following we will start with a brief history of the origin of this genre, followed by an analysis of three specific functions of penny prints we identified in both countries. Dutch penny prints have received much attention the last ten years, not least thanks to a group of Dutch expert-collectors who compiled an impressive modern bibliography and study, edited by Nico Boerma. ${ }^{23}$ But also long before this monumental work, several scholars were showing an interest in this field, including Maurits de Meyer, C.F. van Veen and Patricia Vansummeren. ${ }^{24}$ From 2010 onwards a Dutch project, led by one of the authors of this article, studied popular adaptations of narratives in penny prints and other cheap material. This has resulted in a number of publications, which are of use for this comparison. ${ }^{25}$ Spanish aleluyas and auques have been studied from the 1930 onwards. The works of scholars such as Joan Amades and Rafael Gayano Lluch, ${ }^{26}$ have opened up this field for further research. ${ }^{27}$ Despite this

21 Boerma et al., op. cit. (n. 2), pp. 122-33; pp. 893-5.

22 Martínez González, art. cit. (n. 4); Botrel, art. cit. (n. 13)

23 Boerma et al., op. cit., (n. 2).

24 M. de Meyer, De volks- en kinderprent in de Nederlanden van de 15e tot de 20 eeuw (Antwerpen/Amsterdam 1962); C.F. van Veen, Centsprenten: Catchpennyprints. Nederlandse volks- en kinderprenten, Dutch Popular and Childrenprints (Amsterdam 1976); Vansummeren, op. cit. (n. 5).

25 R. Harms, 'Popular Culture and Penny Prints: How Eighteenth- and Nineteenth-Century Readers in the Dutch Republic Indirectly Created Their Own Narratives', Cultural and Social History, 12 (2015), pp. 217-34; R. Harms, 'Populaire literatuur in een nieuw jasje: Adaptatiestrategieën in narratieve centsprenten', Spiegel der letteren, 54 (2012), pp. 22757; T. Verheij, 'The Dissemination of a Fairy Tale in Popular Print: Cinderella as a Case Study', in: Cinderella Across Cultures: New Directions and Interdisciplinary Perspectives, ed. M. Hennard Dutheil de la Rochère et al. (Detroit 2016), pp. 113-23; Salman, art. cit. (n. 12); J. Salman, 'Vormvast en betekenisvol: Populaire beeldverhalen in de Nederlandse literatuurgeschiedenis', Spiegel der Letteren, 59 (2017), pp. 291-319; J. Salman et al., Sterke verhalen: Vijf eeuwen vertelcultuur (Nijmegen 2014); J. Salman, 'Devotional and Demonic Narratives in Eighteenth- and Nineteenth-century Dutch Penny Prints', in: Cheap Print and the People: European Perspectives on Popular Literature, ed. D. Atkinson \& S. Roud (Newcastle upon Tyne 2019), pp. 121-38.

26 J. Amades, J. Colomina \& P. Vila, Imatgeria Popular catalana: Les auques (Barcelona 1931); J. Amades, 'Auques y aleluyas', Bibliofilia (1951), pp. 20-1; R. Gayano Lluch, Aucología valenciana: Estudio Floclórico (Valencia 1942).

27 J.-F. Botrel, 'Les 'aleluyas' ou le degré zéro de la lecture', in: Regards sur le XXe siècle espagnol, ed. J. Maurice (Paris 1995), pp. 9-29; Botrel, art. cit. (n. 13); J. Díaz, 'Literatura de cordel: Pliegos y aleluyas', in: Se hicieron literatos para ser políticos. Cultura y política en la España 
history of scholarship, a systematic approach to the Spanish material is still needed. This article aims to show the potential of this rich field and hopefully provides a starting point for studies to come.

\section{Origin and General History}

Although the golden age of Spanish aleluyas was the nineteenth century, their origin was much older. Two earlier forms of popular prints can be considered precursors of aleluyas: the so-called 'auques', which were broadsides consisting of a (not fixed) number of encircled woodcuts without caption, which had been published in the Catalan-speaking regions since the seventeenth century. Their exact meaning and purpose is unclear: it appears that in these early days the auques were associated with some kind of astrological and predicting practices, which were recurrently forbidden by ecclesiastical authorities. The oldest preserved auca was published in Moià in 1676 by the printer Pere Abadal. Shape and function of the auques evolved over the centuries, solidifying at the end of the eighteenth century into the standardised format described earlier: a broadsheet consisting of 48 woodcuts with a square (not circular) shape. The second form, present in the Castilian-speaking areas, were the 'aleluyas', prints conceived to be used in religions celebrations of Easter Sunday and Corpus Christi. The illustrations, always of saints and biblical characters, were cut out and thrown into the air by the people during the processions. It was common practice to write the word aleluya at the bottom of each woodcut, from which they received their genre name. The conjunction of these two print traditions resulted in what we now refer to as aleluyas, a term that lost its religious connotation in the nineteenth century. The Catalan printer Joan Maria Marés played a central role in this conversion. He moved from Barcelona to Madrid in 1831, and started to print auques, a type of print which was still unknown there. He was one of the first printers who added a rhyming caption to the illustrations. Because of the similar shape between 'auques' and 'aleluyas', the prints by Marés and other printers were known as 'aleluyas' in Madrid, and this meaning became common elsewhere very soon. Under the influence of Catalan auques, the traditional aleluya incorporated new secular themes and functions. ${ }^{28}$

The early Dutch prints did not differ much from the Spanish ones. The fifteenth and sixteenth century penny prints, known as 'heiligen' (saints),

de Carlos IV y Fernando VII, ed. J. Ȧlvarez Barrientos (Cádiz 2004), pp. 63-82; Martínez González, art. cit. (n. 4). 
contained one or a few woodcuts with images of biblical figures and saints, and had a spiritual function as well, safeguarding people against diseases, dangers and other misfortunes. That is why they often were pinned to the wall or pasted inside travelling trunks. Obviously, these Catholic religious prints lost their popularity in the seventeenth-century, Calvinistic, Dutch Republic. ${ }^{29}$ Devotional prints did not disappear completely in the market for cheap print, but the Protestant ones were less prominent, had a different function, and represented other images, such as from the Old Testament. ${ }^{30}$ In the (Catholic) Southern Netherlands however, the 'heiligen' retained their important religious function until the nineteenth century, with a focus on themes as the veneration of the Virgin Mary, hagiolatry and the New Testament. ${ }^{31}$

In the Dutch Republic more secular themes started to dominate the market for penny prints from the 166 os onwards. Only roughly $10-20 \%$ of the titles produced in the Northern Netherlands in the eighteenth century consisted of religious works. ${ }^{32}$ A game changer was a pedagogical-ideological institution that started to interfere in the production of Dutch prints at the end of the eighteenth century. The enlightened, civilizing, upper-middle-class Maatschappij tot Nut van 't Algemeen (Society for Common Benefit) (established in 1784), started to flood the market with edifying penny prints. Penny prints evolved into the epitome of educational reform. ${ }^{33}$

A decisive factor for the success of penny prints and aleluyas was the growing and shifting audience. Due to the low price these prints were affordable for almost all social layers in society. Dutch publishers saw new opportunities from the early eighteenth century onwards and started to address children specifically. Later in the eighteenth and especially in the nineteenth century, penny prints, often supplemented with a moral message, were predominantly aimed at children. ${ }^{34}$ In Spain children became a clear focus as off the nineteenth century as well, with titles such as: 'Mythology for children', 'Children's games', and 'Lottery for children' and so on. However, even if the youth became a clear target for printers of aleluyas, it would be wrong to jump to the conclusion that it was now exclusively part of children literature. The topics, aims and, thus, audiences of aleluyas in Spain remained varied during its whole existence.

\footnotetext{
29 Van Veen, op. cit. (n. 24), pp. 9o-1; Boerma et al., op. cit. (n. 2), pp. 320-2.

$30 \quad$ Boerma et al., op. cit. (n. 2), pp. 316-17, pp. 323-8.

31 Vansummeren, op. cit. (n. 5), pp. 129-33.

32 Boerma et al., op. cit. (n. 2), p. 325.

33 See J. Thijssen, 'Leerzaame prentjens voor de jeugd': Schoolprenten van de Maatschappij tot Nut van 't Algemeen (Utrecht 2009).

Boerma et al., op. cit. (n. 2), pp. 27-9.
} 


\section{A Range of Functions}

In both countries, penny prints covered a wide range of topics, comprising religious, literary, historical, educational and satirical material. Congruent to this multifaceted content are the varied and changing functions of penny prints and aleluyas in the course of four centuries. Comparing the Spanish with the Dutch material we were able to distinguish at least six functions. ${ }^{35}$ 'Functions' entails here all kinds of publisher and distribution strategies as well as different reading and user practices. These functions were not mutually exclusive and often occurred side by side. First of all, we note a substantial group of prints aimed at popularising and adapting theatre plays. Second is the function of standardisation of (folk/fairy) tales over a long period of time. The third function entails the adaptation and popularisation of literary classics. The fourth could be described as enhancing religious rituals, festivities and piety. The fifth function is serving and addressing new audiences (lower classes, children, peripheral languages). A sixth and final function involves the supporting, evading or resisting of edifying strategies initiated by ideological institutions. In the following we will highlight the intriguing and illuminating differences and similarities between Spain and the Netherlands, focusing on three prominent and exemplary functions: theatre plays; folk/fairy tales; and literary classics.

\section{The Adaptation and Popularisation of Theatre Plays}

In both countries we observed a notable connection between the theatre, particularly comical plays, and penny prints. In some Dutch cases prints were meant as souvenirs after the audience left the theatre, perhaps to be used to memorize or recite the narrative. In other cases penny prints seem simply to have been inspired by the original play, and publishers created a related, or indeed completely new, adaptation of the story. ${ }^{36}$ Angela Vanhaelen identified another function for Dutch prints, namely the fact that they were a response to the more strict classicist criteria that were applied by the Amsterdam theatre from 1677 onwards. Penny prints would have satisfied the market for comical narratives about family life and marriage. ${ }^{37}$

35 See Boerma et al., op. cit. (n. 2); Salman, art. cit. (n. 12), pp. 20-47; Salman, art. cit. (n. 25: 2019), pp. 121-138.

36 Salman, art. cit. (n. 25: 2019).

37 A. Vanhaelen, Comic Print and Theatre in Early Modern Amsterdam: Gender Childhood and the City, (Aldershot and Burlington 2003), pp. 7-9; see also a critical response in Boerma et al., op. cit. (n. 2), p. 22. 
In the Dutch context prints about love life and marriage seem to have their origin in seventeenth century comical plays and farces. Some examples are Geveynsde bedelaar of Herstelde liefde [The feigned beggar or recovered love] (1661), by Adriaan van Steyn, Jan Klaasz of Gewaande Dienstmaagt, [Jan Klaasz or Imagined Housemaid] (1682) by Thomas Asselijn and De Vryagie van Jan de Plug, en Caat de Brakkin [The love affair of Jan de Plug and Caat de Brakkin] (c. 1691-1692) (anonymous). These three plays ended up in some form in a penny print, often with other than the original titles. In this last case the 'souvenir' function does not seem obvious. It was more likely that the print publisher used the play to create his own narrative.

The first farce, Geveynsde bedelaar of Herstelde liefde (1661), is about the divorce and reunion of the couple Urbanus and Isabel. Urbanus and Isabel end up in a fight soon after their marriage and Urbanus leaves the house, in the possession of Isabel's money and jewels, soon after a hurried divorce. From then on, he leads a loose, wandering life in which he wastes all her money. After a while he returns as a beggar to Isabel's home with his tail between his legs. He asks for forgiveness, but Isabel shows no mercy. Eventually, however, she complies, and they are reunited again and even get married for the second time. ${ }^{38}$ This story was very successful in the format of a printed 'dialogue' but less popular as a performed theatre play. The eighteenth-century penny print contained elements of the dialogue as well as the play, but lacked a moral meaning. In a later, nineteenth century, version of this penny print, aimed at children, the crude language has disappeared, family life is centre stage and the story has recovered the edifying flavour. ${ }^{39}$ The pattern we see here is that in the popularisation process the narrative maintains its entertaining function and loses its moral connotation. As a result of the nineteenth-century educational and pedagogical reforms, the morality returns again, but then adapted to and aimed at children.

The second play (The Love Affair of Jan de Plug and Caat de Brakkin) looks like a scabrous farce but in fact contained a delicate discussion about the religious-philosophical ideas of the Dutch minister Balhasar Bekker, who denied the existence of the devil. ${ }^{40}$ A penny print with the title 'Dronken Jan en Vuile Kaat' [John the Drunkard and Dirty Kate], published by the Erven Wijsmuller [Wijsmuller heirs] in Amsterdam, was based on this farce, albeit

38 Salman, art. cit. (n. 25: 2019).

39 This penny print was published in Rotterdam and was entitled: Zie hier ô Jeugd, Voor tydverdryf/Hoe dat Urbanus en zijn Wyf/Die eerst in ongenoegen leven/Elkander alle leed vergeven. [Watch you youngsters, as a pastime, how Uranus and his wife, who first lived in discord, now have forgiven each other].

Salman, art. cit. (n. 25: 2019), pp. 129-33. 
that the story was completely altered. The philosophical reference had disappeared and only the quarrels and the drinking had remained. The explanation for this is that in the popularisation process the extra layers disappear and the story just becomes a form of entertainment. What is more, the publisher used for this story the woodblocks of another penny print about a kitchen maid (Steven, Dear Steven) and just changed the names. ${ }^{41}$ Economic and costsaving incentives were at play here, but this choice also amplifies the notion that the texts was key and the images had a more impressionistic function in the narrative. ${ }^{42}$

In Spain, there had been a close relationship between theatre and 'literatura de cordel' since the seventeenth century. ${ }^{43}$ Various types of popular prints made complete plays or parts of them known to the general public. For example, 'relaciones de comedia' contained the most famous monologues from the theatrical works of the seventeenth century, while 'comedias sueltas' and 'entremeses' provided the complete text of individual plays. In the nineteenth century, aleluyas helped to establish an even closer link between theatre and 'literatura de cordel'. Especially from 1850 onwards, aleluyas made the public familiar with all the types of plays that were being performed then: Romantic drama, realist theatre, 'comedias de magia', adaptations of serialised novels and zarzuelas. There were even aleluyas that described the theatre world itself and the process of putting on a play. We can see this in the aleluya 'Una representación dramática' [A Dramatic Performance] (Madrid, Fernández-Gonzalo de Córdoba), which gives a detailed portrait of an evening at the theatre: the posters announcing the play and the sale (and resale) of tickets, the various locations of the seats, depending on social status, the behaviour of the audience, the parts of the entertainment, the best or worst performance given by the actors, and so on.

According to Diego Visone, two functions of Spanish theatre aleluyas can be clearly identified. ${ }^{44}$ Firstly, in the 185 os and 1860 os aleluyas performed a moralising function connected with edifying dramatic texts, with the aim of preserving and disseminating the message of the play that was performed. What was important in these aleluyas was the plot of the play, but there was no mention

\footnotetext{
41 This is a tale about a clumsy servant, which dates from roughly $1738-67$ and was published by Gysbert de Groot Keur in Amsterdam.

42 Salman, art. cit. (n. 25: 2017), pp. 307-12. See for more about this tale of the kitchen maid Harms, art. cit. (n. 25: 2015), pp. 217-34.

43 S. Cortés, Literatura de cordel y teatro en España (1675-1825). Estudio, Catálogo y biblioteca digital de pliegos sueltos derivados del teatro, http://pliegos.culturaspopulares.org.

44 D. Visone, 'Le aleluyas teatrali', in: Literatura popular. Simposio sobre literatura popular, ed. J. Díaz (Urueña 2011), pp. 76-103.
} 
of the performance. Instead there was a summary of the story, similar to what was done in aleluyas with adaptations of novels. Secondly, from 1867 onwards aleluyas were employed to provide publicity for plays. Francisco Arderiús, a theatre impresario, was the first to use them in this way. These aleluyas give a detailed description of the most spectacular aspects of the production, with references to the costumes, the scenery and the performances of the actors, in order to promote the show. In fact, these advertising aleluyas were sold at the box offices and at the theatre entrances.

In contrast to what was done in the Netherlands, the theatrical aleluyas respected the plots of the plays quite faithfully in their adaptation to a format consisting of 48 pictures. It is true that the limitation of space made it necessary to select the most sensational and spectacular situations and the main episodes and characters, but that did not mean that the plot of the play was altered. We can see this in the aleluyas that adapted the various genres of theatre: Romantic dramas such as El trovador [The Troubadour]', written by Antonio García Gutiérrez and first performed in 1836, 'comedias de magia' such as La pata de cabra [The Goat's Foot] by Juan de Grimaldi (1829), theatrical adaptations of serialised novels such as Los pobres de Madrid [The Poor People of Madrid] by Manuel Ortiz de Pinedo (1856), or zarzuelas such as $E l$ Valle de Andorra [The Valley of Andorra] (1852) by Luis de Olona. ${ }^{45}$

The cases in which the adaptation of a play for an aleluya led to changing the plot were exceptional. One striking example is the aleluya 'De la Tierra al Sol pasando por la Luna' [From the Earth to the Sun by Way of the Moon], in which the first 19 pictures correspond to Jules Verne's novel De la Terre à la Lune and the remainder to Narcís Campmany and Joan Molas's zarzuela De la Terra al Sol, with pictures giving a head-and-shoulders portrait of each of the characters and showing some of the main scenes. The ensuing result was hugely confusing. ${ }^{46}$

\section{Standardising and Popularising Folktales}

Within the wide topic of folk and fairy tales we decided to focus on a wellknown, transnational, allegorical narrative: the World Turned Upside down. This humoristic formula was already famous in the middle-ages and resonated in printed form in many countries and many languages from the sixteenth

45 S. García Castañeda, 'El teatro del XIX en los pliegos de cordel', in: Díaz, op. cit. (n. 44), pp. 189-212.

46 Visone, art. cit. (n. 44), pp. 95-9. 
(44.)

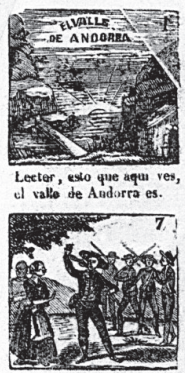

Vichor y sus counpaneros

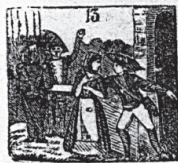

Vietor, que sslís soldacto,

se deserta despechedo.

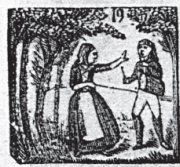

Loisas i Colks, despreeiado

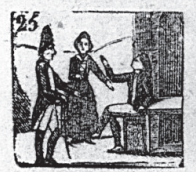

Se muestra Coles propicio

pers enganebarse al servicio.

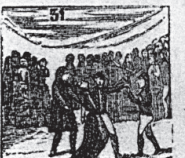

Por el preblo reehazada

Harie cae denasyade.

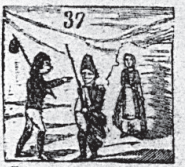

Colis heliowio at sargenso,

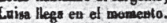

43

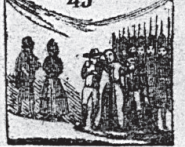

EL VALLE DE ANDORRA.

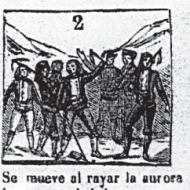

e maeve al rayar la aur ora Marceto el pastor, la suert
de Loiga y Teresa advierte.

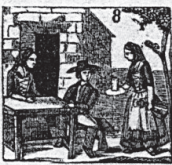

Vietor sentado a la mesa,

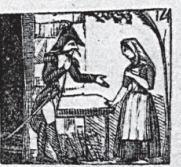

Por librarle, trabla María

al capitan Alegria.

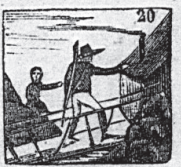

Vietur, Heno de alegria, voelve th case do Maris.

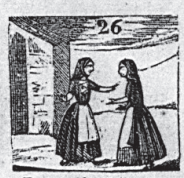

Teresa pide su llave,
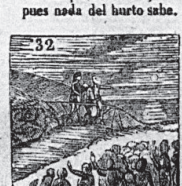

Libras a Saris jura

Vietor, de tal impostura.

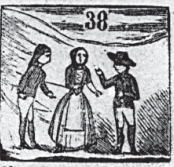

Vietor, sabe que no ha sies the quien le ba redinide.

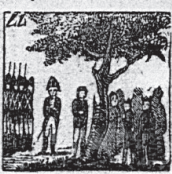

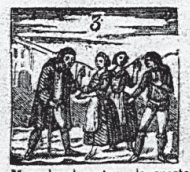

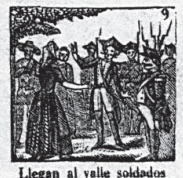

Llegan al valle soldados por Alegria mandados.

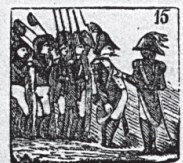

de Vietor la desereion.

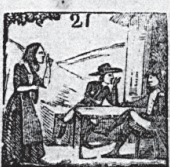

Yietor, saber quién ha sido quiere yuibán le ba redienido.

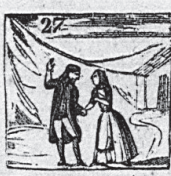

Pide a Mureelo Maria

dimero. El no lo tenia.

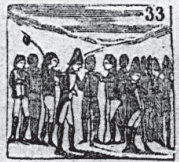

Cuesta el conitan

lo historia de Rademanto.
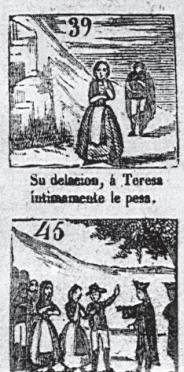

Apercibe el pelotos.

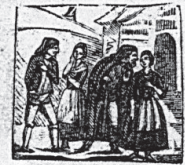

$\longrightarrow$ seses

ofrece á Teresa amor.

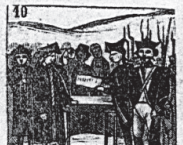

LCES 15119

Da prinerpio la sneints

ceremonia de la quinta.

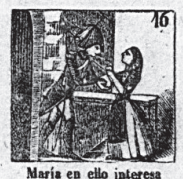

Maria en ello interesa

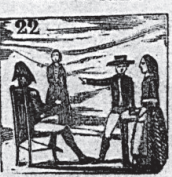

María, breve y coneisa,

$$
\text { le diee que ha sido Luisa. }
$$

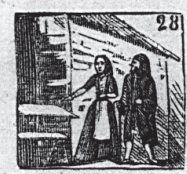

Teresa enenentra at contado

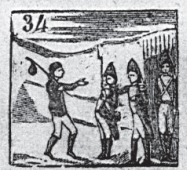

Colla trege se preats

porque geatas presenta,

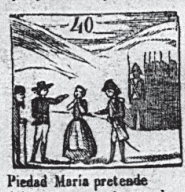

Piedad Maris preteade
del capitan, que la prende.

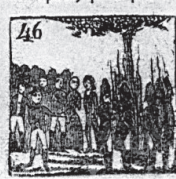

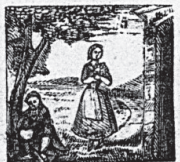

Maris da sus amores

á un ramillete de flores. Te sa tesoro 3 Mark.

20 II

12 bijitis

2.

(1) 10

CLL $[1]=1$

Cuando sale libre un moso

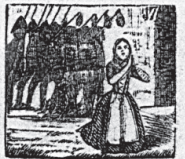

Librande á Vietor la suerto

Marin sn accion adrierte.

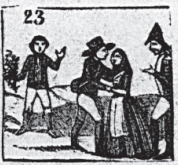

Tl mone sil verle presente,

abritzala tiernamento. sufrit do Loisa el desprecio.

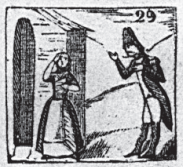

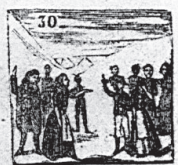

Que á Vietor salird Maria Ante el pueblo congregado. dice as Teress, Alegria.

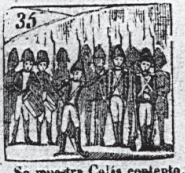

el hurto deanociado.

$536-7 x$ wass

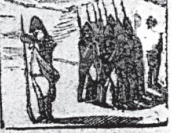

Se muestra Colís contento, Bl capitas Alegria,

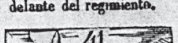

vase of prender \& Marí.

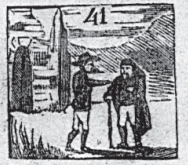

Marceito, hercanas sabio

que eran Teresa y Maria.

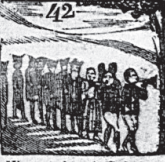

Viene a dar el Tribuas

Q7.

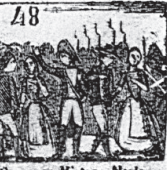

Figure 1 El valle de Andorra [Andorra Valley], Despacho de Marés y Compañía, Madrid (between 1842 and 1874).

FUNDACIÓN JOAQUÍN DÍAZ 
century onwards. In the collections of Spanish aleluyas and Dutch penny prints we found similar examples of ironic inversion, but it was easy to find examples in Italy, France and Germany as well. When we had a closer look at this whole European repertoire, we discovered all sorts of transnational exchange, adaptations, and translations and imitations.

Boerma et al. made a useful distinction between a general series of prints around the world turned upside down, and a group of prints that each represented a particular theme, such as the henpecked husband, the Land of Cockaigne, or the spinning or fighting animals. ${ }^{47}$

An example of a Dutch penny print that represents the general theme is 'Alles wat gij ziet zijn zeer verkeerde zaken [...]', [All you see are things turned upside down], printed by J. Noorduijn, Gorinchem, between 1819 and 1840.48 This print presents a range of 20 funny scenes, such as the beggar who gives money to the benefactor, the bear who leads his boss, the gravedigger who is buried by the dead, and a cat who flees the mouse. Similar scenes are depicted in a French allegorical (engraved) print that is entitled L'homme appuyé sur sa/ tête joue de la basso/ de viole sans dessus dessous, [A man standing on his head is playing the bass violin] (Basset, Parijs, c. $\left.{ }^{1805}\right) .{ }^{49}$ In this print we see people literarily standing on their heads and even some captions are turned upside down. People are hunted at, grilled and have to pull a wagon filled with horses.

The world turned upside down was also an extremely successful subject in Spanish aleluyas. There was almost no publisher of aleluyas that did not publish at least one edition of 'El mundo al revés' [The world turned upside down]. In comparison with Dutch penny prints, aleluyas offered a greater number of scenes with inverted roles because the Spanish format contained more pictures (usually 48). There is very little variation between the individual publications: animals making men work (horses, oxen, asses), animals hunting, cooking or eating human beings (sheep, turkeys, partridges, pigs, fish), pupils teaching schoolmasters, children scolding parents, women and men dressed in each other's clothes, poor people giving alms to the rich, blind people acting as guides, men carrying off the devil, human beings slaying death, and so on. In some cases the caption accompanying the picture was limited to a short phrase ('Escuela sin maestro' [School without a teacher], 'El gato en la jaula' [The cat in the cage], 'La oveja pastora' [The shepherding sheep]), while in others the scene was described in couplets ('El toro mata al torero, / esto sí que es verdadero' [The bull kills the bullfighter / this is really true], '¿Este niño por

47 Boerma, et al., op. cit. (n. 2), p. 351. See also Salman, op. cit. (n. 25: 2014), pp. 23-41.

48 This penny print is part of the Arie van den Berg collection, Allard Pierson Amsterdam.

49 This penny print is part of the Arie van den Berg collection, Allard Pierson Amsterdam. 


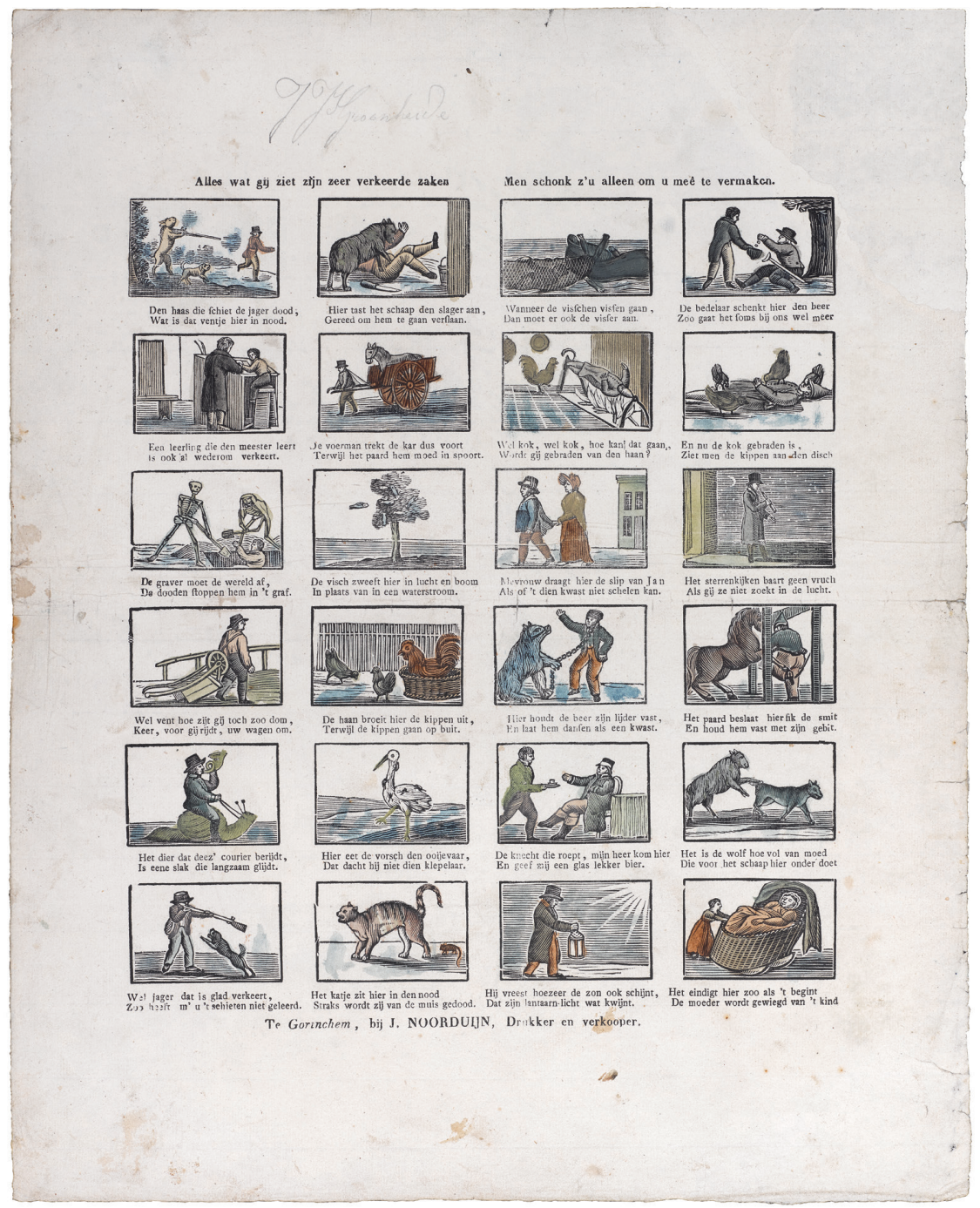

FIGURE 2 Alles wat gij ziet zijn zeer verkeerde zaken [...], [All you see are things turned upside down], J. Noorduijn, Gorinchem, (between 1819 and 1840 ARIE VAN DEN BERG COLLECTION, ALLARD PIERSON AMSTERDAM

ventura / la doctrina enseña al cura?' [Is this child by chance / teaching doctrine to the priest?]). Manuel Bellver y Tomàs, the author of the auca published by the printworks managed by his brother, Blas Bellver, in Xàtiva, wrote phrases that were not a mere description of the scene but rather what the individual characters said about their unlikely situation, giving their point of view. For 
FL MUNDO AL REVÉS.
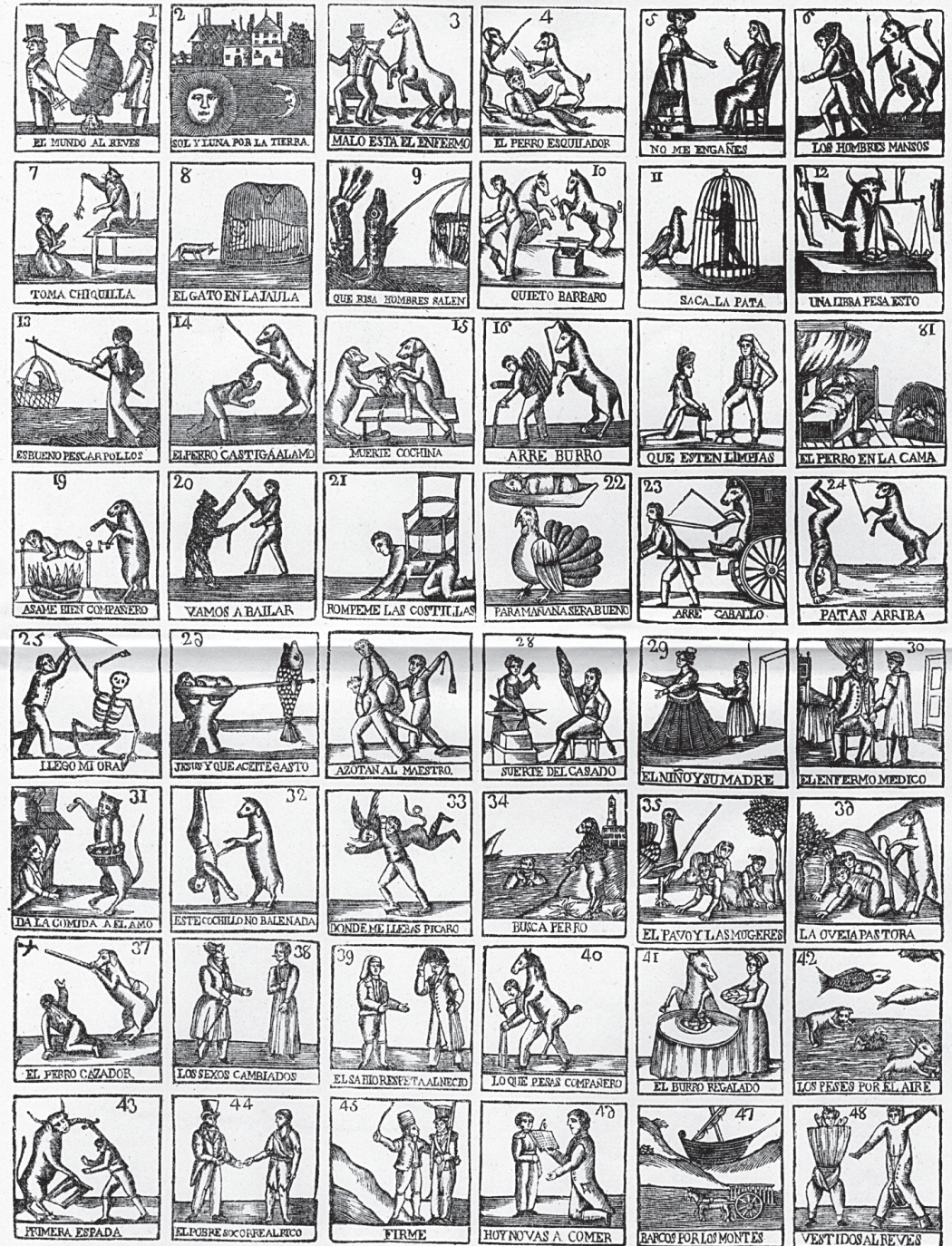

Barcelona: en casa Juan Llorens, calle de la Palma de santa Catalina.

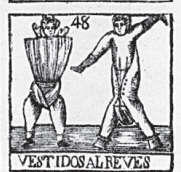

FIGURE 3 El mundo al revés [The world turned upside down]. Juan Llorens, Barcelona (between 1855-1870)

FUNDACIÓN JOAQUÍN DÍAZ

example, some pigs that are cooking a man say 'A las quince debe estar, / según puedo calcular' [By three he should be done, / according to my reckoning], and a rabbit that is hunting a man exclaims ‘'Vaya un tiro con certeza! / He muerto 
una buena pieza! [What a splendid shot! I've killed a good specimen!].50 Many of these pictures with implausible situations were subsequently printed individually in sets of collectible picture cards about the world turned upside down in the early years of the twentieth century. ${ }^{51}$

The popular theme of the world turned upside down seemed to fit perfectly well in the format of European penny prints. Via European wide distribution channels such as that of the Italian Remondini, prints with this theme probably reached many European countries and audiences. Italian prints must have had a (renewed) impact on the production of penny prints or aleluyas as well. ${ }^{52}$ The European wide success of the world turned upside down was probably also due to the possibility this medium offered to visualise this metaphor in multiple ways without a very explicit and worked-out narrative. Furthermore, people everywhere in Europe were familiar with the feast of carnival and recognized and enjoyed the humoristic flavour immediately.

\section{The Adaptation and Popularisation of Literary Classics}

\section{Don Quixote}

The adaptation of such a classic as Don Quixote into a penny print of 12 images and captions is perhaps one of the most remarkable achievements of the penny prints compilers. Especially when we consider the fact that the story comprised two thick volumes with multiple episodes, storylines, allusions and satirical anecdotes. What makes it a bit more comprehensible is that the story was first abridged into children's literature before it found its way into a penny narrative. Compared to other classics, the popularisation of Don Quixote occurred rather late and does not seem to have led to many variants. The number of preserved penny prints is low and they were all produced in Belgium in the nineteenth century. Two woodcuts were produced by the publishers Hemeleers-Van Houter (1827-1894) from Schaarbeek. The print publisher Gordinne (c 1894-c 1945) from Liege produced a series of three (subsequent)

50 V. Pla Vivas, La ilustración gráfica del siglo XIX: Funciones y disfunciones (Valencia 2010), pp. $176-7$.

51 J. M. Martínez González, 'Efímeros pluscuam(im)perfectos: Literatura infantil y juvenil en los cromos españoles de la primera mitad del siglo XX', in: LIJ Efímera: La perfecta imperfección de los no libros, ed. J.M. Martínez González \& R.J. Freire Santa Cruz (Cuenca 2018), pp. 15-73.

52 See G. Mori \& A. Perin, Il mito del paese di Cuccagna: Immagini a stampa dalla Raccolta Bertarelli (Pisa 2015), pp. 138-40; A.W.A. Boschloo, The Prints of the Remondinis: An Attempt to Reconstruct an Eighteenth-Century World of Pictures (Amsterdam 1998), pp. 177-82. 
lithographical prints (numbers 133-134, 135). One (very sloppy) Hemeleers print has captions in French and some in Dutch (12 woodcuts). This last penny print does not have any borders between the images. The woodcuts look as if they were intended to be cut out. The other Hemeleers prints (16 woodcuts) have captions only in French, so this one must have been aiming at a French or Wallonian audience exclusively. The Gordinne editions, which have more in common with the modern comic strips, have versions in French ('Aventures de Don Quichotte') and Dutch. Most of these prints show the iconic scenes, such as the battle against the windmills, whilst in some cases the story has radically changed. An eyecatcher is the version where the story loses all its irony and wit, and Don Quixote turns out to be a serious knight. In the Gordinne print Don Quixote retains his sanity as in the original story, but instead of dying he stays alive and dedicates the rest of his life to counselling his countrymen. ${ }^{53}$

Contrary to the Dutch situation, and not surprisingly, the adventures of Don Quixote became a great success in the form of aleluyas, and there were numerous editions of the story from the early nineteenth century onwards. The first ones were very simple, with just a series of episodes portrayed in each picture. This is elucidated by the aleluya published by Ignacio Estivill, with 48 numbered pictures. In the first one the face of the central character appears alongside the title 'Vida de Don Quijote' [Life of Don Quixote]. The others correspond with various chapters from Cervantes's book, without any attempt to offer continuity of the story: 'Aventura de la batalla del vizcaíno' [Adventure of the battle with the Basque] (7) - 'Puñadas en la venta por causa de Maritornes' [Blows at the inn because of Maritornes] (8) - 'Mantean a Sancho Panza' [They toss Sancho Panza in a blanket] (9). We might say that the aleluya is a mere enumeration of some of the episodes in Cervantes' novel, requiring prior knowledge on the part of the reader in order to understand the picture that illustrates the title of each scene. Understanding the story could prove even more difficult in the case of episodes that appear in the wrong order, as we can see in an aleluya published in the early nineteenth century: the arrangement is so chaotic that we begin to wonder whether this aleluya was designed to be cut up and put in order by the reader. However, this is an exceptional case; the other known editions present the story in the standard order, and from the middle of the nineteenth century onwards two lines of verse were added below each picture, describing the scene. We can see this in the versions published by José María Marés and his successors: 'Es Don Quijote encantado / y en una jaula encerrado' [Don Quixote is enchanted / and shut up in a cage], 'De una isla gobernador / hace a Sancho su señor' [By his master, Sancho is made / the 


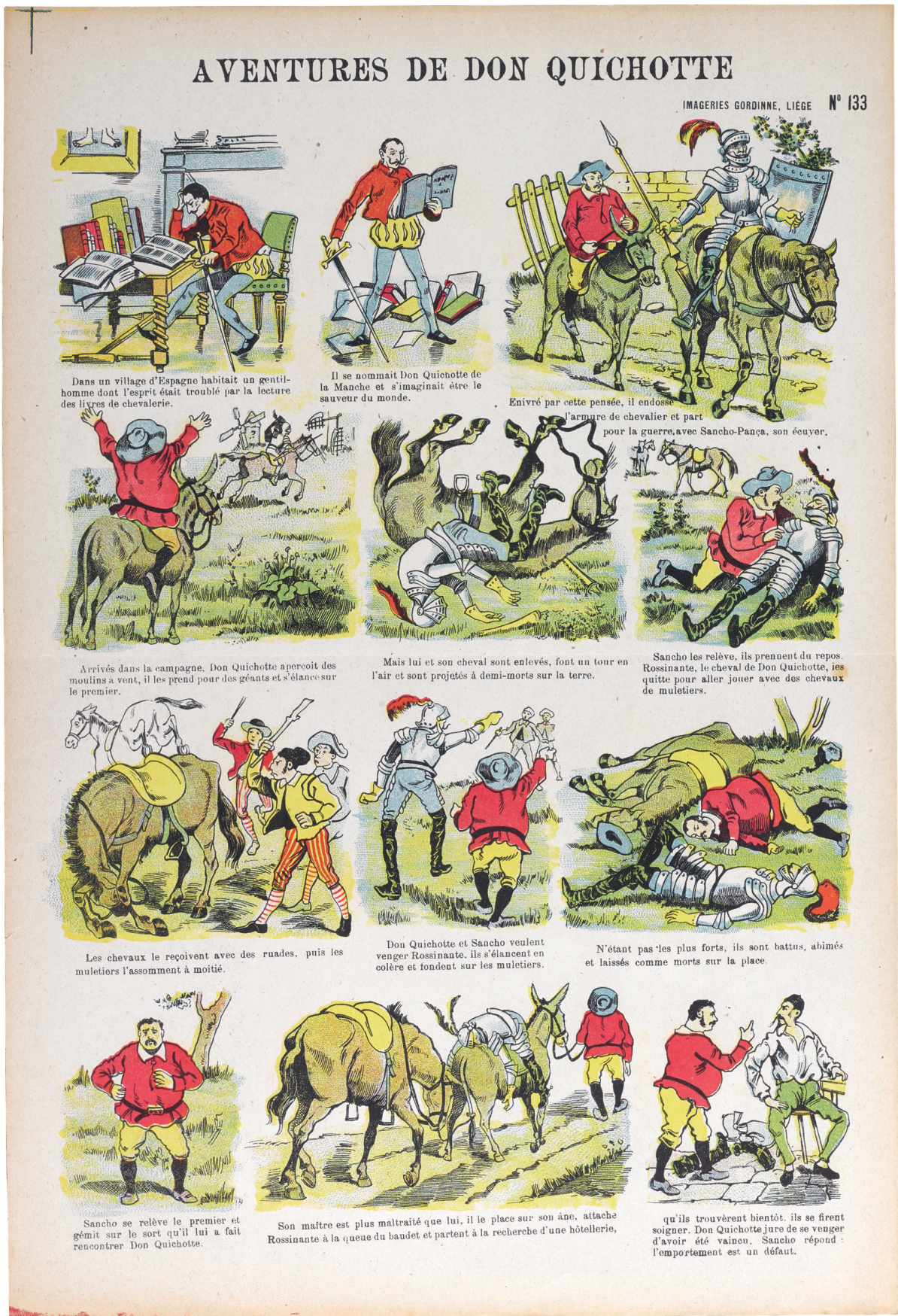

FIgure 4 Aventures de Don Quichotte. Gordinne, Liege (1893-ca. 194X), no. 133 NICO BOERMA COLLECTION, ALLARD PIERSON AMSTERDAM 
Nưm, $17 \mathrm{~h}$

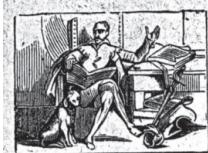

Es curiosa y dirertida
de D. (ovijote la vida.

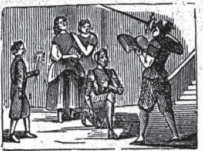

Por el miemo mesoner

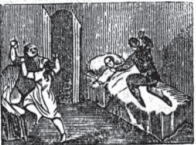

De Maritories preadado

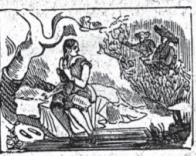

orotea es descubierts

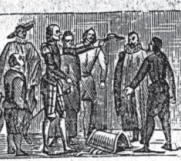

La bacia, el yelmo tino
disputa ser de Mambrino.

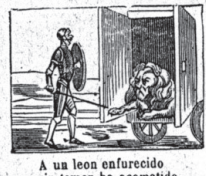

A ui leon enfurecido

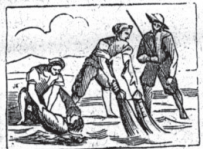

Del molino los eriado

los sacen a medio ahogados:

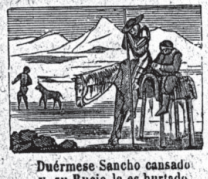
Duérmese Sancho cansado
AVENTURAS DE DON OULJOTE DE LA IIANCHA.

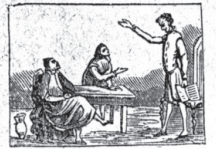

Con el barbero y el cura
disputa

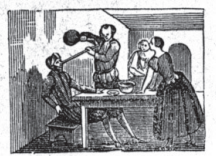

Pur la celada con mana

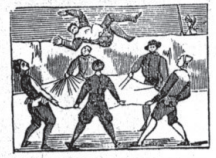

Como un pelete touado

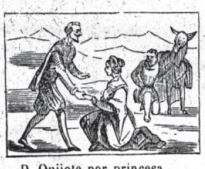

D. Quijote por princesa
la toma, y sus plantas bess.

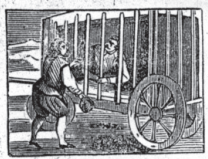

Es D. Quijote encantado
y ea una jaula eacerrado

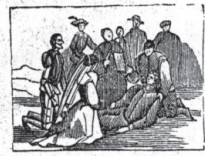

A sisten sin gran empacto

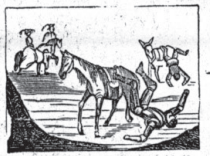

Tan vergonzosa caida

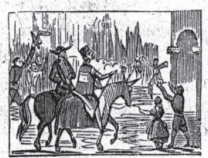

Cuando en Barcelona en traron

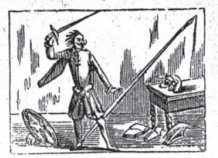

Con recios golpes de espa pruelia la dura celada.

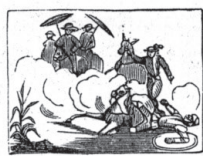

De un mereader el criado
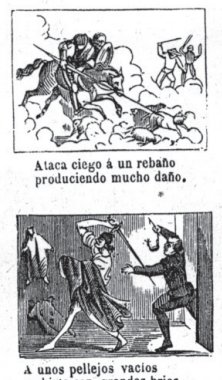

a unos pellejos vacios

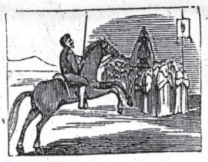

Bl values te campeon
dispersa una procesion.

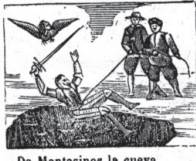

De Montesinos la cueva
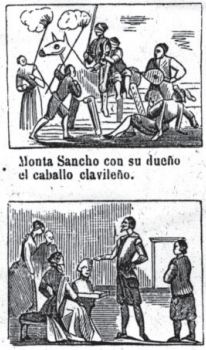

A D. Quijote enseñada.

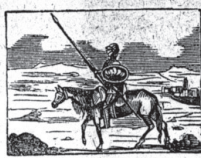

Cuntinuando sus locurảs

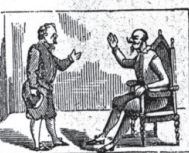

De essudero a Sancho Panza recibe con conflanza.

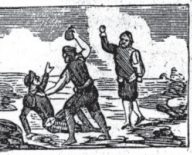

Camioaudo por un prado
por Cardeaio es maltratado.

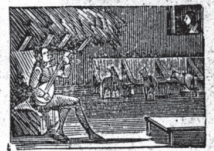

Do mozo de mulas canta

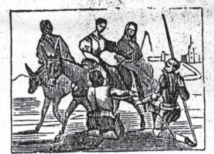

Creyendo ser Dulcinea

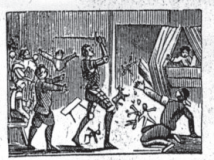

Hiere D. Quijote fiero
á un pobre titiritero.

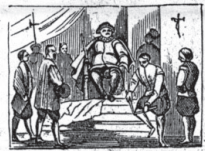

Ue una isla gobernador
hace à Sancho su senor.

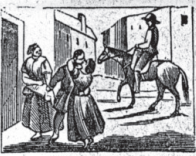

A su pueblo al lin regresa
porque la edad ya le pesa.

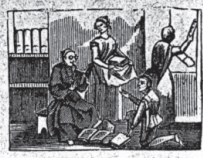

Cuando verlo no prodia

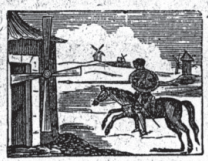

A unos molinos de viento
embisto con ardimizuto.
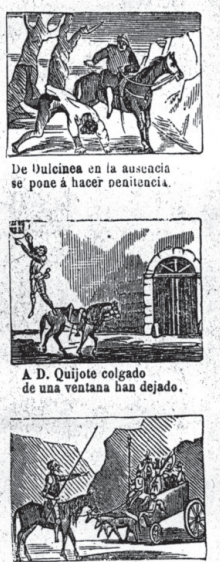

A toda una companía

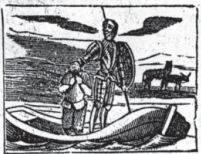

Quiere con Sancluo embarcarse con graa peligro de ahogarse.

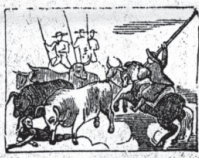

Unos toros le acometen
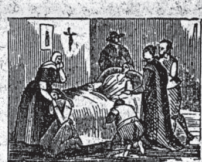

Unia corts entermedad
lo lleva a la eternidad,

MADRID,-Despacho, calle de Juanelo, núm, 19.

FIgURE 5 Aventuras de Don Quijote de la Mancha [Don Quijote de la Mancha Adventures]. Despacho de Marés y Compañía, Madrid (between 1842 and 1874) FUNDACIÓN JOAQUÍN DÍAZ 
governor of an island]. We could say that these aleluyas offered a fairly complete, schematic summary of Cervantes' novel, although, of course, no trace of the irony and complexity of the narrative remained. There were interesting versions of the story of Don Quixote, such as the aleluya titled 'Vida del gran Sancho Panza' [Life of the great Sancho Panza], printed by the Tabernillas publishing house (Madrid) at the end of the nineteenth century, which offered a summary of the novel seen from the viewpoint of the famous squire. He was made into the real central character of the story, from his birth to his return home. Another interesting version of Cervantes's work is the aleluya titled 'Historia del nuevo Don Quijote' [Life of the new Don Quixote], published in Barcelona by the Imprenta de Sucesores de Antonio Bosch in the last quarter of the nineteenth century. This was really a political satire that ridiculed the central character, a politician of the time whose identity is unknown. He is portrayed as a new Don Quixote, and his crazy, imprudent, unscrupulous conduct leads to his death after he has been completely abandoned. ${ }^{54}$

\section{Robinson Crusoe}

The 1719 novel of Daniel Defoe about the adventurer Robinson Crusoe has such an overwhelming history of translations, adaptations and abridgements, that it is difficult to know where to start. We will limit ourselves to some general observations. In the Dutch case we see the recurring pattern of a transition from a translation, to an abridgment for children to finally a penny print version. A pedagogical adaptation that had an important intermediate role in these adaptations was J.H. Campe's Robinson der Jüngere (1779-1780). His work was soon translated into Dutch and must have functioned as a rich source for penny prints, especially the ones with a strong moralistic connotation. A Dutch penny print produced by the publisher Hoffer, for instance, referred directly to this German example. ${ }^{55}$

The penny narratives around Robinson show some serious changes. The focalization of the story changed, because an external storyteller replaced the first-person narrator (Robinson himself). The result was that also the selfreflections of the protagonist had vanished. Still, most of the prints follow the original sequence of the story and reveal iconic scenes: the shipwreck, the building of his house, the discovery of the footprint, the encounter with cannibals and Friday and the escape with a stranded ship. Scenes that made the

54 J. Givanel Mas y Gaziel, Historia gráfica de Cervantes y del Quijote (Madrid 1946).

55 Boerma et al, op. cit. (n. 2), pp. 401-2; S. Parlevliet, Meesterwerken met ezelsoren: Bewerkingen van literaire klassiekers voor kinderen 1850-1950 (Hilversum 2009), pp. 193-6, pp. 228-33. 
narrative too complicated or demanded a more detailed explanation, such as Robinson's illness, were erased. ${ }^{56}$

Some prints ignore the fictional character of the book and state that Robinson Crusoe was in fact Alexander Selkirk, the Scottish sailor who really lived on a deserted island for four years. Selkirk was indeed a source of inspiration for Defoe, but the novel did not reveal this authentic story. It appears that the fictional features of the novel went (consciously or unconsciously) lost in the process of popularization. What is more, the penny prints for children disseminated a moral message, congruent to Campe's adaptation, that deviated strongly from the original story. Some prints taught the children that Robinson should not have been disobedient towards his father. ${ }^{57}$ Some versions stressed Robinson's disobedience towards God and social order. ${ }^{58}$ In this line of reasoning his stay on the Island should be interpreted as a punishment for his sins. Other penny narratives ignore the sinfulness and remorse completely. ${ }^{59}$ Finally there are editions devoid of any moralization. ${ }^{60}$ They just start with Robinson seeking his luck elsewhere and end with the happy news that he could escape the remote island and returned to England. ${ }^{61}$

In Spain, the story of Robinson Crusoe was adapted as an aleluya by the printer José María Marés (Madrid), who published it several times. As in the case of Don Quixote, and as in the Dutch penny prints about Robinson, the account loses all the richness of Defoe's novel and is reduced to a mere sequence of episodes. The 48 pictures follow the adventures of the central character in considerable detail: his journeys before he reaches the island are mentioned, although most of the pictures concentrate, naturally, on the strategies and inventions he devises in order to survive on the island. Some minor changes with respect to the original work are introduced, such as the name of the savage freed by Robinson, who is called Domingo [Sunday] rather than Viernes [Friday], as in various Spanish translations of the novel, and the way the story ends, concluding with the re-encounter of Robinson and his ancient father, an ending that is pure invention. Like in the aleluyas about Don Quixote, in the case of Robinson there are interesting versions inspired by Defoe's novel. One example is the Catalan aleluya 'El Petit Robinson' [Little Robinson]. ${ }^{62}$ This publication was not based on the English novel but on a similarly titled zarzuela,

\footnotetext{
56 Harms, art. cit. (n. 53), pp. 116-18.

57 See the edition Wijnhoven Hendriksen, series no. $27=$ Lutkie series no. 42.

58 E.g. the editions of De Lange and Hoffer (series no. 19).

59 See edition Noorduyn (series letter P).

6o See editions Glenisson and Brepols.

61 Boerma et al., op. cit. (n. 2), pp. 401-2; Parlevliet, op. cit. (n. 55).

62 García Castañeda, art. cit. (n. 45), p. 207.
} 


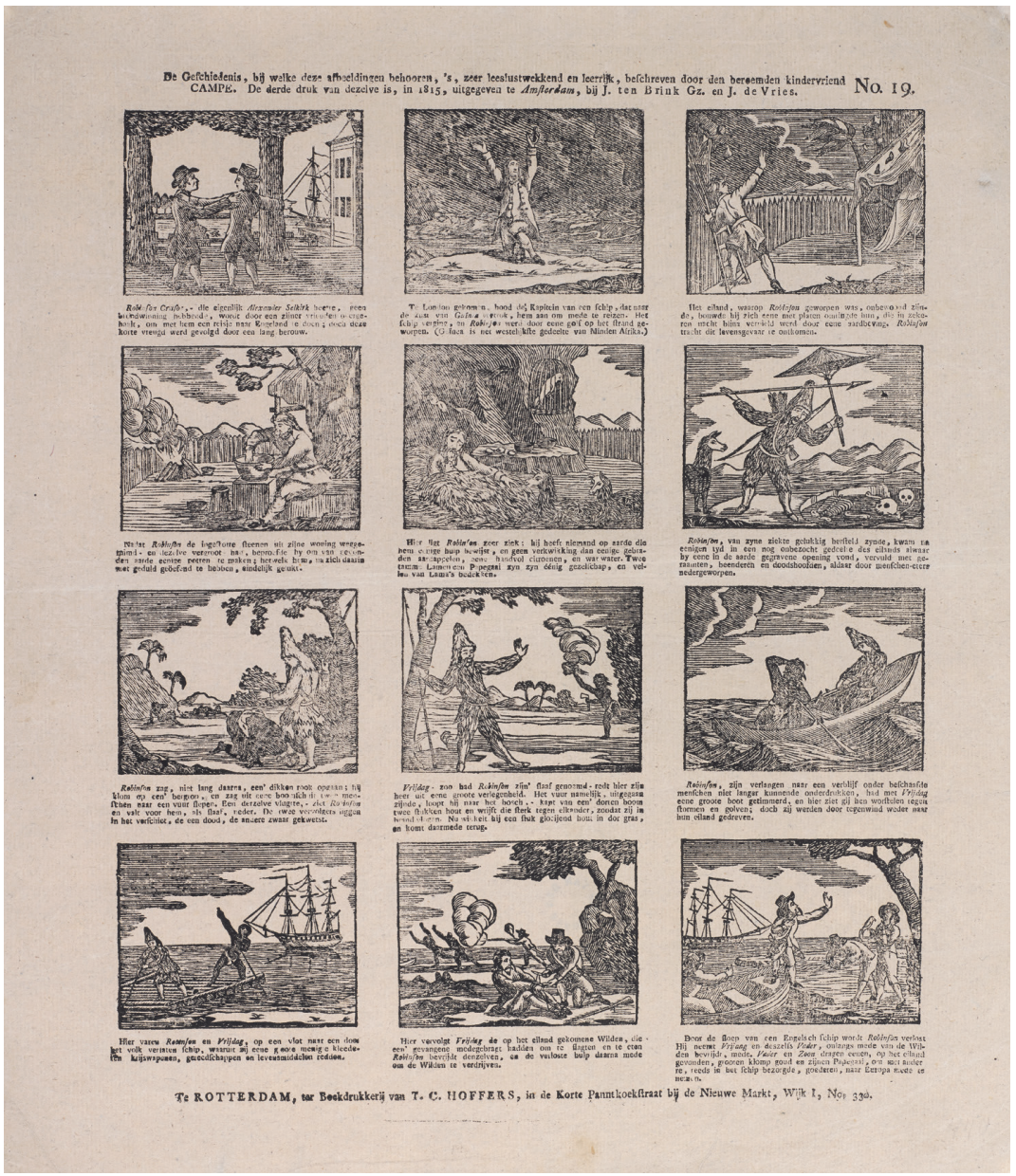

FIGURE 6 De geschiedenis, bij welke deze afbeeldingen behoren [The history, to which these images belong], T.C. Hoffers, Rotterdam, (between 1820-1839), No 19. This is a Robinson print, based on the adaptation of Campe ARIE VAN DEN BERG COLLECTION, ALLARD PIERSON AMSTERDAM

composed by Josep Coll i Britapaja, which was premiered with great success at the Circo theatre in Barcelona in 1871. This work was, in turn, a parody of the zarzuela Robinson (1870), with music by Asenjo Barbieri, an adaptation of the comic opera Robinson Crusoe by Jacques Offenbach (1867). The zarzuela presents the central character as an anti-hero who lives by practising deceit and running up debts. After leaving his wife he is pursued by his creditors, who decide to teach him a lesson by making him believe that he has travelled to a Pacific island. It is interesting that the aleluya 'El Petit Robinson' focuses 
on the stage production of the zarzuela, mentioning the theatre where it was performed and describing the entrances and exits of the characters and the costumes. It is a further example of the close relationship established between the theatre and aleluyas in the second half of the nineteenth century, when, as we have already seen, aleluyas were used as a way of informing the public about theatrical productions.

\section{Concluding Remarks}

In this final section we would like to highlight some striking differences and similarities between the Spanish aleluyas and Dutch penny prints. A first topic is the transition from a predominantly religious, towards a more profane content. An indirect result of the struggle between the Low Countries and Spain was the establishment of the Calvinistic Dutch Republic with high literacy rates, a blooming publishing industry and relatively little (or ineffective) press control. In this new context penny prints not only lost their function in Catholic rituals, but could also without any restriction be filled with a variety of secular and entertaining content. In the Southern Netherlands, however, the share of religious penny prints remained higher until the nineteenth century. The Spanish transition to more secular prints was not caused by a specific historical event. It occurred in the nineteenth century as a result of innovative publishing strategies: a group of publishers started to merge the more secular Catalan auques with the traditional aleluyas.

The different economic, social and cultural developments in the Dutch Republic as compared to Spain, are probably also an explanation for the discrepancy in the growth of production. In the Dutch Republic the 'Golden Age' of the penny print was the eighteenth century, whereas in Spain a substantial growth occurred in the nineteenth century. When we looked at similar patterns in publishing strategies and the exploration of different functions, this discontinuity did not impede the comparison. But when we searched for a more direct exchange of content or transnational adaptations of penny prints, we could only focus on the nineteenth century.

Another interesting finding is the interaction of the penny prints with ideology and social order. In many cases the Spanish and Dutch examples just conformed to current ideologies and institutions, but often they also ignored religious and moral conventions in favour of unpretentious entertainment. In some cases, penny prints and aleluyas were instruments of political satire or evasions to resist pedagogical and social reforms. A main difference is the fact that Spain lacked the educative and edifying impact of an enlightened 
ideological institution such as the Dutch Society for Common Benefit. This means that the large corpus of school prints that was produced alongside the regular penny prints, was absent in the Spanish market. In Spain, as far as we know, there was no attempt by the political and cultural elites to employ aleluyas for ideological purposes, as happened around other popular prints such as romances. ${ }^{63}$

In both countries we encountered similar functions, such as the adaptations of literary classics, the standardisation of tradition folk stories and the relation between theatre plays and penny prints. Similarly, we observed in both countries processes of adaptation, abridgment (for children for instance), reduction and simplification. More sophisticated literary ingredients such as satire, political critique and metafiction disappeared in penny prints and aleluyas. The narratives now and then underwent such radical alterations that the plot, function and characters became unrecognisable. We did see some instances of transnational exchange, although it was difficult to determine in what direction these influences went. Some strange twists in the adaptations of the original narratives, such as Robinson Crusoe's reunion with his father, occurred in both countries and seem to suggest imitation. An explanation could be that, certainly in the nineteenth century, big publishing houses in Belgium, Germany and France produced bilingual editions and distributed their products in several European countries.

Considering material differences and similarities we noticed that the paper used for Spanish aleluyas was coloured, contrary to the Dutch (white, yellowish) ones. In the Dutch prints the woodcuts were often coloured by hand, which does not seem to be common in the Spanish ones. Spanish publishers used coloured paper probably to make the aleluyas more appealing. Another difference that struck us was the number of woodcuts per sheet, which was remarkably higher in the aleluyas than in the penny prints. Consequently, substantial classics such as Robinson Crusoe and Don Quixote were done more justice in the aleluyas than in the penny prints. Is this perhaps an indication of the fact that Dutch publishers tried to adapt the story to a specific audience of children, whereas in Spain most prints continued to address all kinds or readers?

On the other hand, it remains problematic to determine exactly what would make a suitable adaption for children. Despite the fact that in Spain as well as in the Netherlands, at least in the nineteenth century, many penny prints aimed at children in the titles ('dear children'), the content was certainly not

63 J. Gomis, 'Echoes from the Middle Ages: Tales of Chivalry, Romances and Nation-building in Spain (1750-1850)', Studies in Medievalism, 24 (2015), pp. 93-113. 
always very 'childlike'. We came across multiple scabrous, satirical, seditious, violent and political examples. On the other hand, our view on what would be suitable for children is different from that in the nineteenth century. ${ }^{64}$ In a way penny prints and aleluyas created a paradox that has continued in comic strips: in theory aimed at children, but enthusiastically read by adults as well. ${ }^{65}$

64 See Verheij, art. cit. (n. 25), pp. 113-23.

65 Research for this chapter was funded in part by the Spanish Ministry of Science, Innovation and Universities (PGC2018-097445-A-C22) and by the Valencian Conselleria of Innovation, Universities, Science and Digital Society (GV/2020/207). 